\title{
SIGNIFICANCES OF MARKETING EDUCATION IN REDUCING POVERTY IN INDONESIA: SPECIAL REVIEW ON QUALITY OF LIFE
}

\author{
Senny Luckyardi \\ Department of Management, Universitas Pendidikan Indonesia, Bandung, Indonesia \\ Department of Management, Universitas Komputer Indonesia, Bandung, Indonesia \\ Ratih Hurriyati \\ Department of Management, Universitas Pendidikan Indonesia, Bandung, Indonesia \\ Disman Disman \\ Department of Management, Universitas Pendidikan Indonesia, Bandung, Indonesia \\ Puspo Dewi Dirgantari \\ Department of Management, Universitas Pendidikan Indonesia, Bandung, Indonesia
}

\begin{abstract}
Poverty in Indonesia has become a critical issue as a result of social and economic disparities. The phenomenon is inextricably linked to education's role as a gateway to poverty alleviation. One of the primary causes of entrepreneurial failure, which ultimately increases the risk of bankruptcy and poverty, is a lack of public knowledge about marketing. From the stated problem, the purpose of this research is to investigate how marketing education can aid in the reduction of poverty in the context of quality-of-life improvement. Because most previous research focused on unemployment and income levels as indicators of poverty, which did not explain the quality of life comprehensively, a review of the quality of life is required in this study. Additionally, Man Whitney analysis was used to compare the quality of life in the two groups of respondents using a quantitative method. Observations were also conducted for a period of six months to assess the respondents' quality of life. WHOQOLBREF was used as a research instrument and was distributed to Group 1 (30 respondents who had received marketing education) and Group 2 (30 respondents who had not received marketing education). Each respondent is from a different province in Indonesia. The findings indicate that marketing education can help reduce poverty, resulting in significant improvements in quality of life. Marketing knowledge leads to positive changes that have a significant impact on human well-being. This research contributes to our understanding of marketing education as a means of reducing poverty.
\end{abstract}

Keywords: Analysis, Marketing Education, Quality of Life, Poverty, Indonesia

DOI: http://dx.doi.org/10.15549/jeecar.v9i1.867

\section{INTRODUCTION}

The ability to overcome poverty is one of the indicators of a country's successful economic development (Todaro, 2000). The education sector drew the government's attention because there is a strong link between education and 
poverty. Accordingly, Agi and Yellowe (2013) stated that education is critical for the development of Human Resources, knowledge, and attitudes. Because education is a major component in the vicious cycle of poverty, the level of education has an impact on the level of poverty. As a result, improving the quality of education is one way to address the issue. The Human Development Index and the Human Poverty Index are recognized as the more comprehensive approaches to analyzing poverty. This approach includes several dimensions, namely the economic dimension (income), education (literacy), and health (life expectancy) (Chriswardani Suryawati, 2005). Therefore, education is an important factor in overcoming poverty. This statement is in line with the endogenous growth theory proposed by Lucas and Romer, which states that education/human capital affects economic growth and the level of per capita income of a country. Marketing and entrepreneurship education is education that is most closely related to the problem of poverty because it offers solutions for improving welfare and changing mindsets as well as business mentality. Marketing education aims to provide knowledge, skills and motivation to encourage entrepreneurial success in various fields $(\mathrm{J} \mathrm{H}$ Carland, 2007). It was also stated that one of the factors that contribute to entrepreneurial failure is a lack of marketing expertise (Amjad, T., Rani, S. H. B. A., \& Sa'atar, S. B, 2020).

Several studies have been conducted to explain the relationship between marketing education and poverty, but the role of marketing education as a factor that can reduce poverty through successful business has not been highlighted. Furthermore, research on marketing education with a focus on quality of life is something that has received little attention in previous studies. According to O.J.K Ogundele et al. (2012), the federal government has designated entrepreneurship as one of the strategies for reducing poverty and unemployment in Nigeria. According to Ogundele's findings, entrepreneurship training and education have a significant impact on improving welfare and youth empowerment in Nigeria. This study looks at youth empowerment as an indicator of poverty reduction rather than the quality of life or marketing education. According to Gd Brutton, DJ Ketchen, and R D Ireland (2013), providing marketing education to the poor results in long-term solutions to their poverty problems. Despite this, marketing orientation is critical to entrepreneurial success (Boso, N., Story, VM, Cadogan, JW, (2013); Gd Brutton, DJ Ketchen, and RD Ireland (2013)). The review method was used to conduct this study, which included a review of 71 pieces of literature. However, there is no calculation for the percentage improvement in quality of life. Although L Boyer et al. (2014) conducted a study on poverty-related quality of life, this study focuses on health quality. According to Fitri Amalia (2012), education has a significant impact on poverty levels in Eastern Indonesia. This research focuses on the economic dimension, which includes measures of unemployment and inflation rates. In addition to the studies mentioned above, numerous studies have found that education, particularly knowledge of business, marketing, and entrepreneurship, has a significant impact on poverty levels (Rofiq (2015); Yoghi Citra Pratama (2014)). Studies on the impact of marketing education on poverty reduction, with a specific focus on improving quality of life, have received little attention. A comprehensive and multidimensional study regarding the quality of life is required.

Based on these facts, the purpose of this research is to examine how marketing education can help reduce poverty by improving people's quality of life using the Man Whitney quantitative method. In addition, the WHOQOLBREF was used as an instrument to compare the quality of life in two groups of respondents: those who received marketing education and those who did not.

\section{Marketing Education}

Marketing education is a subfield of education that focuses on acquiring formal knowledge or teaching marketing principles and techniques to obtain academic marketing qualifications. It can also be defined as acquiring the knowledge, skills, and experience to recognize customer needs and fulfill them to their satisfaction and benefit. Ferrell et al. (2020) stated that marketing education is education that focuses on distribution, sales, and advertising. This is also supported by Ralph Starr Butler, who defined marketing education as education that integrates sales, pricing, distribution, advertising, and other functions to create 
marketing. Marketing education is education given to those who want to gain knowledge and understanding of marketing principles and basic marketing skills. Since marketing is a moneymaker for companies, it is a powerful education. It determines whether a company is successful in meeting its objectives. Being customer-centered encourages organizational and customer interaction. It introduces businesses and customers to each other. It allows the many functional units of the organization to work together. Marketing education's overarching goals are to provide students with sufficient knowledge in sales, advertising, and marketing to get a job or continue their studies in college; to train managers who can build their own; to equip students with basic and advanced marketing concepts; to promote effective marketing management, and to produce qualified and competent marketing professionals.

\section{Poverty}

According to Suparlan (2000), poverty is a state of complete lack of assets and valuables suffered by a person or group of people who live in an environment of poverty or lack of capital. This lack of capital can mean a lack of money, knowledge, social, political, and legal power, and access to public service facilities, business, and work opportunities. There are six main problems with poverty: (1) the problem with poverty is vulnerability. For example, farmers' incomes can increase with infrastructure development in agriculture, but a long-term drought will reduce their standard of living to their lowest point. One of the main problems of poverty is the economic condition of farmers, who are very vulnerable due to seasons or changes in policies in agriculture. (2) Poverty means that access to various job opportunities is closed due to low competition due to a person's low bargaining position. Exploitative work situations, long working hours, and low pay are examples of this poverty problem. (3) Poverty is a problem of emotional and social distrust in dealing with bureaucrats, a lack of opportunities for selfactualization, a lack of financial resources to pay for health care, and living in a dirty or public environment. (4) Poverty results in a nutritional deficiency. Income is used up for consumption. (5) Poverty is defined as having a high economic reliance (dependence) on others, having a low intelligence level, and having limited access to education. (6) Poverty is usually passed from one generation to the next. In addition, according to Sumodiningrat (1999), there are five classes of poverty classification, namely: absolute poverty, (2) relative poverty, (3) structural poverty, (4) chronic poverty, and (5) temporary poverty.

\section{Quality of Life}

Quality of life, according to WHO, is an individual's perception of their position in life in the context of the culture and value systems in which they live and in relation to their goals, expectations, standards, and concerns. Quality of life is a broad concept that is impacted in complex ways by a person's physical health, psychological state, personal beliefs, social relationships, and relationship to salient features of their environment. The term "quality of life" is used to evaluate the general well-being of individuals and society as a whole. This term can be applied to various fields, including international development, health, and politics. The quality of life is often misunderstood as the standard of living, the indicator of which is mainly seen from the level of income. In contrast, quality of life standards indicators includes wealth, employment, the built environment, physical and mental health, education, recreation and leisure, and social belonging. The definition of quality of life is explained through the quality of life indicators.

An indicator of the quality of life allows a person to estimate their degree of well-being. The Quality of Life Index is a composite index of three indicators: life expectancy, death rate, and literacy rate. Since 1990, the United Nations Development Program (UNDP) has developed an index known as the HDI. The HDI explains how the population can access development outcomes regarding income, health, and education. HDI is formed by three basic dimensions: a. long and healthy life; $b$. knowledge; and c. a decent standard of living. Another indicator besides HDI is PQLI, a noneconomic index that is a combination of 3 indicators

\section{METHOD}

The Mann-Whitney analysis was used to compare the quality of life in the two groups of 
respondents using a quantitative method. Observations were also conducted for a period of six months to assess the respondents' quality of life. On the other hand, this study relied solely on primary data. WHOQOL-BREF, a shortened version of WHOQOL-100, is a tool for assessing quality of life. WHOQOL-BREF is made up of 26 items/questions divided into four domains: physical health, psychology, social relationships, and the environment (See Table 1). The WHOQOL-BREF instrument was given to two groups of respondents, each with 30 people, and if there were any questions, the interviewer could provide assistance in filling it out. The data were collected from the first group, which had received marketing education, and the second group, which had never received marketing education. The data for the second group comes from an economically disadvantaged community where no marketing education has ever been provided. On August 20, 2018, data for the two groups were collected in the Binongjati area of Bandung, West Java.

The WHOQOL-BREF score has been translated into Indonesian and is given a score covering four domains: I Physical domain (7 questions); ii) Psychological domain (6 questions); iii) Social Relations domain (3 questions); and iv) Environment domain (8 questions). Each question was assigned a score ranging from 1 to 5 , with a higher score indicating a higher quality of life. The domain score is calculated by multiplying the mean of each set by 4 . If the respondent does not answer at least $20 \%$ of the questions, the domain is not scored. MannWhitney analysis was used to examine data from the WHOQOL-BREF questionnaire. In general, Mann-Whitney analysis was used to compare two groups of respondents.

\section{RESULTS AND DISCUSSION}

Table 2 describes the results of the descriptive analysis of Domain 1 (Physical Health) in the group that received marketing education. The results obtained showed that domain 1 (physical health) in the group of respondents who were given marketing education was in a good category $(72.19 \%)$.

Table 1: Domain WHOQOL - BREF

\begin{tabular}{|l|l|}
\hline \multicolumn{1}{|c|}{ Domain } & \multicolumn{1}{|c|}{ Factors involved in domain } \\
\hline \multirow{4}{*}{ 1. Physical health } & Daily activities \\
\cline { 2 - 2 } & Dependence on drugs or medical assistance \\
\cline { 2 - 2 } & Energy and exhaustion \\
\cline { 2 - 2 } & Mobility \\
\cline { 2 - 2 } & Pain and discomfort \\
\cline { 2 - 2 } & Sleep and rest \\
\cline { 2 - 2 } & Work capacity \\
\hline \multirow{5}{*}{ Psychology } & Idea and appearance \\
\cline { 2 - 2 } & Negative feelings \\
\cline { 2 - 2 } & Positive feelings \\
\cline { 2 - 2 } & Confident \\
\cline { 2 - 2 } & Spirituality/religion/belief \\
\cline { 2 - 2 } & Thinking, learning, memory and concentration \\
\hline \multirow{5}{*}{ 3. Social relations } & Personal relationship \\
\cline { 2 - 2 } & Social support \\
\cline { 2 - 2 } & Sexual activity \\
\hline & Financial sources \\
\cline { 2 - 2 } & Freedom and physical and mental safety \\
\hline & Health and social care: accessibility and quality \\
\hline & Home environment \\
\hline
\end{tabular}


Table 1: Continued

4. Environment

Opportunity to acquire information and skills

Participation and opportunities for recreation

Physical environment

(pollution/noise/congestion/climate)

Transportation

Source: WHO, 2018

Table 2: Results of Analysis on Domain 1 (Health)

\begin{tabular}{|c|c|c|c|c|}
\hline \multirow{2}{*}{ Statement } & \multicolumn{2}{|c|}{ Receiving Marketing Education } & \multicolumn{2}{c|}{ Not Receiving Marketing Education } \\
\cline { 2 - 5 } & $\%$ & Category & $\%$ & Category \\
\hline Q3 & $68.00 \%$ & Good & $52.00 \%$ & Quite Good \\
\hline Q4 & $80.67 \%$ & Very Good & $39.33 \%$ & Not Good \\
\hline Q10 & $64.67 \%$ & Good & $50.67 \%$ & Quite Good \\
\hline Q15 & $78.67 \%$ & Good & $45.33 \%$ & Quite Good \\
\hline Q16 & $70.67 \%$ & Good & $56.00 \%$ & Quite Good \\
\hline Q17 & $69.33 \%$ & Good & $52.67 \%$ & Quite Good \\
\hline Q18 & $73.33 \%$ & Good & $44.67 \%$ & Quite Good \\
\hline Average & $72.19 \%$ & Good & $48.67 \%$ & Quite Good \\
\hline
\end{tabular}

The average physical health in the group that did not receive marketing education was 48.67 per cent, which was in the quite good category. People who do not receive marketing education have lower incomes because there is no stimulation to change their life motivation. There is a lack of knowledge about starting a business. Those with little business motivation and a low income. The low level of income and limited access to various social welfare facilities will make it difficult to meet various needs for nutritious food or the ability to fight disease, so it is not surprising that the infant mortality rate in their environment is high. Malaria, tuberculosis, eye disease, kwashiorkor, and other diseases threaten economically vulnerable groups as a result of low resistance. It means they have a short life expectancy and a high mortality rate. This group of poor people tends to avoid health facilities that require costs, such as outpatient care, to delay hospital services, to avoid using expensive specialist services, to shorten hospitalizations, to buy half or even a third of prescribed drugs so that they do not undergo total treatment, to seek local treatment that sometimes has harmful effects, and to give birth at home with the assistance of traditional birth attendants, which increases the risk of delivery and the risk of death. Patients suffering from kidney failure are more likely to have their treatment delayed, canceled, or discontinued.
Patients frequently self-medicate, which leads to complications. Abortion rates are rising as a result of rising costs and socioeconomic consequences. Due to a lack of funds, patients refuse or postpone surgical procedures.

Table 3 describes the descriptive analysis of Domain 2 (Psychology) results in the marketing education group. The results obtained indicate that domain 2 (psychology) in the respondents who were given marketing education are in a good category (70, 44\%). Meanwhile, the results obtained in the group who were not given marketing education were $48.67 \%$ in the quite good category. In the theory of Felce and Perry (1996), it is stated that psychological well-being includes influence, fulfillment, stress and mental state, self-esteem, status and respect, religious beliefs, and sexuality. In old age, a person will experience physical, cognitive, and psychosocial life (Papalia, Olds, \& Feldman, 2001; Ariyanti, 2009). Stability in psychological well-being is one factor that plays a role in improving psychological well-being (Renwick \& Brown, 1996). People in poor conditions also tend to close themselves off because they experience a sense of self-doubt. 
Table 3: Results of Analysis on Domain 2 (Psychology)

\begin{tabular}{|c|c|c|c|c|}
\hline \multirow{2}{*}{ Statement } & \multicolumn{2}{|c|}{ Receiving Marketing Education } & \multicolumn{2}{c|}{ Not Receiving Marketing Education } \\
\cline { 2 - 5 } & $\%$ & Category & $\%$ & Category \\
\hline Q5 & $71.33 \%$ & Good & $48.67 \%$ & Quite Good \\
\hline Q6 & $70.67 \%$ & Good & $45.33 \%$ & Not Good \\
\hline Q7 & $70.67 \%$ & Good & $50.00 \%$ & Quite Good \\
\hline Q11 & $65.33 \%$ & Good & $53.33 \%$ & Quite Good \\
\hline Q19 & $75.33 \%$ & Good & $48.67 \%$ & Quite Good \\
\hline Q26 & $69.33 \%$ & Good & $46.00 \%$ & Quite Good \\
\hline Average & $72.19 \%$ & Good & $48.67 \%$ & Quite Good \\
\hline
\end{tabular}

Psychological health refers to positive affect, spirituality, thinking, learning, memory and concentration, self-image and appearance, selfesteem, and negative affect (WHO, 1996; Rapley, 2003). Based on the above theory, psychological well-being is one factor that determines the quality of human life. Psychological factors are important factors for individuals to exercise control over all the events they experience in life; likewise, with the poor. The decrease in psychological ability is caused by the vulnerability of conflicts with family or the environment due to a lack of funds or facilities and a lack of funds and facilities to reduce stress, such as recreation or joining social groups. They are

Table 4 describes the descriptive analysis of Domain 3 (Social Relations) results in the marketing education group. The results obtained indicate that domain 3 (Social Relations) in the respondents' given marketing education is in a good category $(72.22 \%)$. Meanwhile, the group not given marketing education showed a lower number, namely $50.89 \%$, which was in the quite good category.

Table 4 : Results of Analysis on Domain 2 (Social Relations)

\begin{tabular}{|c|c|c|c|c|}
\hline \multirow{2}{*}{ Statement } & \multicolumn{2}{|c|}{ Receiving Marketing Education } & \multicolumn{2}{c|}{ Not Receiving Marketing Education } \\
\cline { 2 - 5 } & $\%$ & Category & $\%$ & Category \\
\hline Q20 & $73.33 \%$ & Good & $50.00 \%$ & Quite Good \\
\hline Q21 & $69.33 \%$ & Good & $49.33 \%$ & Quite Good \\
\hline Q22 & $74.00 \%$ & Good & $53.33 \%$ & Quite Good \\
\hline Average & $72.22 \%$ & Good & $50.89 \%$ & Quite Good \\
\hline
\end{tabular}

Quality of life is known as an indication of the level of social functioning in mental health (Menlowics \& Stein, 2000; Shahrir et al., 2006). This is important in supporting social relations (social belonging) and community relations (community belonging), which is the bond that a person has with his social environment, including being happy with friends, having social relationships, being active, and not having difficulties in social relationships. Spiritual and social activities will provide the highest value for a person to find meaning and a sense of selfworth (Syamsuddin, 2008). Per the above theory, social welfare is one of the factors in determining a person's quality of life. Quality of life measurement involves mapping the whole life and considering every event in life or social context that can affect the quality of life of an individual. Using the term "quality" makes us associate it with a standard of perfection related to human characteristics and positive values such as happiness, success, health, and satisfaction, where life indicates that the concept underlines the recognition of the social environment on one's existence.

Table 5 describes the descriptive analysis of Domain 4 (Environment) results in the group that received marketing education. The results obtained indicate that domain 4 (environment) in the respondents given marketing education is in a good category (66.00\%) 
Table 5: Results of Analysis on Domain 4 (Environment)

\begin{tabular}{|c|c|c|c|c|}
\hline \multirow{2}{*}{ Statement } & \multicolumn{2}{|c|}{ Receiving Marketing Education } & \multicolumn{2}{c|}{ Not Receiving Marketing Education } \\
\cline { 2 - 5 } & $\%$ & Category & $\%$ & Category \\
\hline Q8 & $66.00 \%$ & Good & $50.00 \%$ & Quite Good \\
\hline Q9 & $69.33 \%$ & Good & $54.00 \%$ & Not Good \\
\hline Q12 & $57.33 \%$ & Quite Good & $68.00 \%$ & Good \\
\hline Q13 & $70.00 \%$ & Good & $59.33 \%$ & Quite Good \\
\hline Q14 & $56.67 \%$ & Quite Good & $72.67 \%$ & Good \\
\hline Q23 & $69.33 \%$ & Good & $50.00 \%$ & Quite Good \\
\hline Q24 & $68.00 \%$ & Good & $63.33 \%$ & Good \\
\hline Q25 & $71.33 \%$ & Good & $56.00 \%$ & Quite Good \\
\hline Average & $66.00 \%$ & Good & $59.17 \%$ & Quite Good \\
\hline
\end{tabular}

In the group that was not given marketing education, the analysis results showed a figure of $59.7 \%$, or in the quite good category. Quality of life is defined as a person's perception of his position in life in relation to the culture and value system in which he lives, in relation to his goals, expectations, standards, and other points of interest (WHOQOL Group, 1994; Nuran, 2009). Quality of life is a multidimensional concept influenced by personal and environmental factors such as intimate relationships, family life, friendships, the workplace, neighbors, city of residence, settlements, education, health, the standard of living, and country conditions.(Schalock and Parmenter, 2000; Rapley, 2003). Renwick \& Brown (2000) suggest that individuals live in an environment called a "place of residence," so that the quality of life has a close relationship with the environment in which the individual lives. Based on the above theory, the residence must create a peaceful, pleasant, and pleasant atmosphere for its residents so that they can feel at home and like they want to stay in that place. Thus, the elderly will be supported by the environment to achieve a high quality of life. An individual's quality of life is intrinsically related to the quality of life of other people in their environment. It is supported by Goode's (1994; Nuran, 2009) opinion that a person's quality of life reflects the cultural richness of both the person and those around him.

The role of the family is also crucial for someone aspiring to become a marketer. Marketing education can take place from an early age in a family environment. According to Hisrich et al. (2005), parents who have a profession as a marketer inspire children to become marketers. Children learn flexibility and independence from their parents by the example of their childhood. Children are also inspired because they were trained from a young age, brought to their business, helped their parents work at the business, were introduced to their parents' relationships, and inherited their parents' business. Through the family, a marketing mindset is formed. Therefore, interest in marketing grows and develops well in someone who lives and grows in a marketer's family environment. Unfortunately, not all family environments or parents play a good role in forming children's interest in marketing. It is caused by many factors, including limited parental knowledge, the mindset in the family that being a civil servant or employee is safer than being a marketer, the fact that there are no examples of marketers in the family, and others.

\section{Analysis of the Estimated Results of the Role Model of Marketing Education on Poverty Reduction}

Based on the study results, it shows that in all domains, namely the domains of health, psychology, social relations, and the environment, the scores are higher in the first group, consisting of respondents who have been given marketing education, than those who have not been given marketing education.

Tables 6 and 7 show the results of the MannWhitney statistical test. Table 6 shows the mean rank of the health domain in the group that was given marketing education, which was 37.80 , higher than the average rank of the group that was not given marketing education, which was 23.20. 
Table 6: Mann-Whitney test results

\begin{tabular}{|c|c|c|c|c|}
\hline & Receiving Marketing Education & $\mathrm{N}$ & Mean Rank & Sum of Ranks \\
\hline \multirow{3}{*}{$\begin{array}{c}\text { Physical Health } \\
(\mathrm{X} 1)\end{array}$} & Yes & 30 & 37.80 & 1134.00 \\
\cline { 2 - 4 } & No & 30 & 23.20 & 696.00 \\
\cline { 2 - 4 } & Total & 60 & & \\
\hline $\begin{array}{c}\text { Psychological } \\
(X 2)\end{array}$ & Yes & 30 & 39.70 & 1191.00 \\
\cline { 2 - 5 } & No & 60 & 21.30 & 639.00 \\
\hline \multirow{2}{*}{$\begin{array}{c}\text { Social Relations } \\
(X 3)\end{array}$} & Total & 30 & 42.13 & 1264.00 \\
\cline { 2 - 5 } & Yes & 60 & 18.87 & 566.00 \\
\cline { 2 - 5 } & No & 30 & 35.85 & 1074.50 \\
\hline \multirow{2}{*}{\begin{tabular}{c} 
Environment (X4) \\
\cline { 2 - 5 }
\end{tabular}} & Total & 30 & 25.18 & 755.50 \\
\cline { 2 - 5 } & Yes & 60 & & \\
\cline { 2 - 5 } & No & & \\
\hline
\end{tabular}

Table 7: Mann-Whitney test results

\begin{tabular}{|c|c|c|c|c|}
\hline & $\begin{array}{c}\text { Physical Health } \\
(\mathrm{X} 1)\end{array}$ & $\begin{array}{c}\text { Psychological } \\
(\mathrm{X} 2)\end{array}$ & $\begin{array}{c}\text { Social Relations } \\
(\mathrm{X} 3)\end{array}$ & $\begin{array}{c}\text { Environment } \\
(\mathrm{X} 4)\end{array}$ \\
\hline Mann-Whitney U & 231.000 & 174.000 & 101.000 & 290.500 \\
\hline Wilcoxon W & 696.000 & 639.000 & 566.000 & 755.500 \\
\hline Z & $-3 . .321$ & -4.132 & -5.200 & -2.388 \\
\hline $\begin{array}{c}\text { Asymp.Sig. (2- } \\
\text { tailed) }\end{array}$ & .001 & .000 & .000 & .017 \\
\hline Grouping Variable: Marketing Educated & & \\
\hline
\end{tabular}

The significance value of 0.001 is smaller than 0.05 , indicating a significant difference between the groups given marketing education related to physical health. It explains that the hypothesis in this study is accepted. A provision for someone to change their economic condition is marketing education. Good economic conditions will lead to better access to health facilities. In line with this, Remi and Priyono (2002) state that several factors cause a decrease in environmental health and an increase in the poverty rate. These factors are natural. The existing industry is not adequate for the absorption of local workers. The physical factors fostered, namely the condition and provision of public facilities and infrastructure, are still very lacking. Socioeconomic factors can be classified into two categories: internal factors from within the region and external factors from outside the region, and socio-cultural factors, such as population, economic level, education level, and culture. The education and health sectors have a positive and significant effect on economic growth, and economic growth has a negative, although not significant, effect on poverty reduction. Likewise, Suwardi's research (2011) explains that local government expenditures allocated to education and infrastructure (roads, irrigation) can significantly affect agricultural productivity and the number of poor people.

The mean rank in the psychological domain shows that the group that was given marketing education was 39.70 , higher than the average rank of the group that was not given marketing education, which was 21.30. The significance value of 0.001 is smaller than 0.05 , indicating a significant difference between the groups given marketing education related to psychological health. Psychologically, people classified as poor usually have low self-esteem and are indifferent or passive towards the surrounding environment. It causes the poor to remain in poor conditions. As a result, they usually do not participate in community activities and tend to close themselves off. According to Ortigas (2000), the above is called the cycle of poverty, and to change the mindset of the poor, this cycle of poverty must be stopped or cut so that the poor are not forever trapped in poor conditions. Therefore, the poor must be given counselling to believe and instil in their minds that they have certain abilities and skills that will ultimately lead them to a better life. Of course, this can 
work well if it is supported by sustainable marketing education for the economically weak population. If this group is provided with provisions through knowledge and education, self-confidence will grow, and they will have the proper self-esteem to compete healthily in the world of work. Therefore, when the poor are in difficult conditions, it is hoped that they will deal with it and not easily give up or despair.

The mean rank in the social relations domain shows that the group given marketing education is 42.13 , higher than the average rank of the group that is not given marketing education, which is 18.87 . The significance value of 0.001 is smaller than 0.05 , indicating a significant difference between the groups given marketing education related to psychological health. Dimensions of social relations include personal relationships, social support, and social activities. Personal relationships are individual relationships with other people. Social support describes the assistance received by individuals from their environment. This relationship in the form of competition is a form of social relations between citizens that can be positive or negative. This negative form will take the form of conflict. In poor communities, conflict occurs between family relationships and the environment. Competition for basic needs with very limited access to employment increases conflict and crime between them. Dependence on the environment is very high, which makes the mentality of people who are included in the poor category generally have a high level of dependence. Marketing education is one solution to forming a confident and independent mind and behavior. A person who opens a new job opportunity is also required to socialize and network with the environment. It makes marketing education significant in improving the quality of life in terms of social relationships.

The social dimension of poverty is defined as the lack of social networks and supportive structures to increase one's productivity. Two inhibiting factor causes the lack of a network: from a person or group (for example, because of the level of education or cultural barriers) and the other from obstacles from outside one's ability (for example, because of bureaucracy or official regulations that can prevent them from taking advantage of existing opportunities). In most developed countries, the transition from traditional society to modern society has been successful. But for people in developing countries (third world), when they seek modernity, they face socio-cultural barriers in the form of traditional values that are very strong in all aspects of life. It causes them to live in underdeveloped, undeveloped, and developing countries. The strength of traditional cultural values causes people's living conditions to become static, not yet experiencing structural differentiation so that political, social, economic, and cultural developments do not progress significantly. Traditional societies are characterized by complex and irregular family structures consisting of various generations, and the number of family members is enormous. The family is responsible for the continuity of offspring, the household economy, education, and welfare.

The average ranking in the environmental relations domain shows that the group given marketing education is 35.82 , higher than the average rank of the group that is not given marketing education, which is 25.18. The significance value of 0.001 is less than 0.05 , indicating a significant difference between the groups given marketing education regarding psychological health. The behavior of slum residents towards fulfilling housing needs illustrates how bad their environment is. The choice of location to build housing is highly dependent on economic conditions. Given the location, health problems and other problems are not a criterion because there is no cost. They build buildings on vacant land that the owner has not used so that it can be used for a while without incurring the cost of buying or renting land. The land condition is not suitable for construction and must receive special treatment so that it can function as a proper place to live. The houses above watersheds, watersheds, and under bridges are usually where they build houses. This bad environment makes marketing education very important to improving their quality of life. With increased income through business, it is hoped that they will have the ability to choose a healthier and better environment.

In relation to various problems and aspects of quality of life, the government needs to incorporate marketing education into the curriculum as early as possible, incorporate marketing training in small business centers, and actively provide marketing training to the poor. 
Government intervention is needed in determining various policies, including facilitating education services and financing, subsidy programs for the poor, increasing community income through job creation, free business training, etc.

\section{CONCLUSION}

Based on the analysis results, it can be concluded that improving the quality of human life can be achieved through good education. The quality of life will increase with marketing education that equips a person with a new way of doing business and a new paradigm to change their destiny. Improved quality of life is in terms of income and non-income, namely health, psychology, social relations, and the environment. Improving the quality of life is one of the most comprehensive indicators of reducing poverty. By comparing the groups who were given marketing education and those who were not given marketing education, it can be concluded that marketing education strengthens all dimensions of human life, including the quality of life, and can ultimately reduce poverty.

\section{ACKNOWLEDGMENTS}

The authors would like to thank the Binongjati knitting center in Bandung, who has been willing to participate in this research. The authors would also like to thank the anonymous reviewer who provided an in-depth review of this manuscript, resulting in a significant improvement in this paper.

\section{REFERENCES}

Abduazimov, M. (2021). Inside Diplomacy during the Pandemic: Change in the Means and Ways of Practice. Indonesian Quarterly, 49(1), 50-66.

Alhashimi, H., Fiallo, A., Freckleton, T. Khalil., M. Mulachela, V and Viera, J (2021). The Future of Diplomacy After COVID-19:

Multilateralism and the Global Pandemic. New York: Routledge.

Barrinha, A., \& Renard, T. (2017). Cyberdiplomacy: the making of an international society in the digital age. Global Affairs, 3(4-5), 353-364.

Anshori, M. F. (2020). Diplomasi Digital Sebagai Dampak Pandemi Global Covid-19: Studi
Kasus Diplomasi Indonesia Di Perserikatan Bangsa-Bangsa (Pbb). Mandala: Jurnal Ilmu Hubungan Internasional, 3(1), 100-119.

Asadi, A. (2017). A Role of Digital Media on Discussing about the Diplomacy in the World. Open Journal of Political Science, 7, 267-275.

Ashish Sharma \& Varsha Sisodia (2021) Digital diplomacy and the global pandemic, Media Asia.

Bjola, Corneliu and Holmes, Marcus (2015). Digital Diplomacy: Theory and Practice. New York: Routledge.

Bull, H. (1997/2002). The anarchical society: A study of order in world politics (3rd ed.). Basingstoke: Palgrave. P.165.

Copeland, D. (2015). Digital technology. In A. F. Cooper, J. Heine, \& R. Thakur (Eds.), The Oxford handbook of modern diplomacy (pp. 453-472). Oxford: OUP.

DDI, Digital Diplomacy Index, 2021. Retrieved from https://digital-diplomacyindex.com/?country=indonesia

Fletcher, T. (2016). Naked diplomacy: Power and statecraft in the digital age. London: William Collins.

Hocking, B., Melissen, J. (2015). Diplomacy in the digital age. The Hague: Clingendael Institute.

IMF (2020), Fiscal Monitor, retrieved from https://www.imf.org/en/Publications/FM/Iss ues/2020/09/30/october-2020-fiscalmonitor

Luerdi, L. (2021) "PARADIPLOMACY OF INDONESIAN SUB-STATE ACTOR: DIGITAL DIPLOMACY OF JAKARTA GOVERNMENT IN RESPONSE TO COVID-19", Berumpun: International Journal of Social, Politics, and Humanities, 4(2), pp. 104-126.

Madu, L., \& Kurniawati, E. (2021, October). Economic Diplomacy Strategies to Increase Indonesian Coffee Exports to Russia in Pandemic Times. In RSF Conference Series: Business, Management and Social Sciences, 1(4), 92-97.

Ministry of Foreign Affairs of The Republic of Indonesia. (2019, September 10). Indonesia Calls for Digital Diplomacy in the Region. Retrieved from https://kemlu.go.id/portal/en/read/584/view 
/indonesia-calls-for-digital-diplomacy-inthe-region

Ministry of Foreign Affairs of The Republic of Indonesia. (2021, November 5).

International Conference on Digital Diplomacy. Retrieved from https://kemlu.go.id/portal/en/read/3125/ber ita/international-conference-on-digitaldiplomacy

Olubukola S. Adesina. (2017). Foreign policy in an era of digital diplomacy, Cogent Social Sciences, 3(1), 1297175.

Purwasito, A., \& Kartinawati, E. (2020, December). Hybrid Space and Digital Diplomacy in Global Pandemic Covid-19. In 6th International Conference on Social and Political Sciences (ICOSAPS 2020) (pp. 662666). Atlantis Press.

Sandre, Andreas (2015). Digital Diplomacy: Conversations on Innovation in Foreign Policy. London: Rowman \& Littlefield.

Syaifani, S., \& Qubba, N. R. (2017). Joko Widodo's digital diplomacy: A prospect and challenge for Indonesia's digital diplomacy towards middle power. Jurnal Hubungan Internasional, 10(2), 106-117.

Yahya, T. (2016, April 22). Digital Diplomasi, Sebuah Kebutuhan Mendesak. Retrieved from https://news.detik.com/kolom/d3194614/digital-diplomacy-sebuahkebutuhan-mendesak

Yasmin, N. (2019, September 10). Foreign Ministry Step Up Game in Digital Diplomacy. Retrieved from https://jakartaglobe.id/news/foreignministry-steps-up-game-in-digitaldiplomacy/

\section{ABOUT THE AUTHORS}

Senny Luckyardi, email:

sennyluckyardi@upi.edu

Senny Luckyardi, Program Studi Doktor Manajemen, Universitas Pendidikan Indonesia.

Ratih Hurriyati, Program Studi Doktor Manajemen, Universitas Pendidikan Indonesia.

Disman Disman, Program Studi Doktor Manajemen, Universitas Pendidikan Indonesia.

Puspo Dewi Dirgantari, Program Studi Doktor Manajemen, Universitas Pendidikan Indonesia. 